\title{
Sensitivity of local air quality to the interplay between small- and large-scale circulations: a large-eddy simulation study
}

\author{
Tobias Wolf-Grosse ${ }^{1}$, Igor Esau ${ }^{1}$, and Joachim Reuder ${ }^{2}$ \\ ${ }^{1}$ Nansen Environmental and Remote Sensing Center, 5006 Bergen, Norway \\ ${ }^{2}$ Geophysical Institute, University of Bergen, 5007 Bergen, Norway \\ Correspondence to: Tobias Wolf-Grosse (tobias.wolf@nersc.no)
}

Received: 5 October 2016 - Discussion started: 24 October 2016

Revised: 11 May 2017 - Accepted: 15 May 2017 - Published: 16 June 2017

\begin{abstract}
Street-level urban air pollution is a challenging concern for modern urban societies. Pollution dispersion models assume that the concentrations decrease monotonically with raising wind speed. This convenient assumption breaks down when applied to flows with local recirculations such as those found in topographically complex coastal areas. This study looks at a practically important and sufficiently common case of air pollution in a coastal valley city. Here, the observed concentrations are determined by the interaction between large-scale topographically forced and local-scale breeze-like recirculations.

Analysis of a long observational dataset in Bergen, Norway, revealed that the most extreme cases of recurring wintertime air pollution episodes were accompanied by increased large-scale wind speeds above the valley. Contrary to the theoretical assumption and intuitive expectations, the maximum $\mathrm{NO}_{2}$ concentrations were not found for the lowest $10 \mathrm{~m}$ ERA-Interim wind speeds but in situations with wind speeds of $3 \mathrm{~m} \mathrm{~s}^{-1}$. To explain this phenomenon, we investigated empirical relationships between the large-scale forcing and the local wind and air quality parameters. We conducted 16 large-eddy simulation (LES) experiments with the Parallelised Large-Eddy Simulation Model (PALM) for atmospheric and oceanic flows. The LES accounted for the realistic relief and coastal configuration as well as for the large-scale forcing and local surface condition heterogeneity in Bergen. They revealed that emerging local breeze-like circulations strongly enhance the urban ventilation and dispersion of the air pollutants in situations with weak largescale winds. Slightly stronger large-scale winds, however, can counteract these local recirculations, leading to enhanced surface air stagnation.
\end{abstract}

Furthermore, this study looks at the concrete impact of the relative configuration of warmer water bodies in the city and the major transport corridor. We found that a relatively small local water body acted as a barrier for the horizontal transport of air pollutants from the largest street in the valley and along the valley bottom, transporting them vertically instead and hence diluting them. We found that the stable stratification accumulates the street-level pollution from the transport corridor in shallow air pockets near the surface. The polluted air pockets are transported by the local recirculations to other less polluted areas with only slow dilution. This combination of relatively long distance and complex transport paths together with weak dispersion is not sufficiently resolved in classical air pollution models. The findings have important implications for the air quality predictions over urban areas. Any prediction not resolving these, or similar local dynamic features, might not be able to correctly simulate the dispersion of pollutants in cities.

\section{Introduction}

Urban air pollution is a major concern for urban dwellers and city managers (Baklanov et al., 2007). Typically, urban air pollution is thought of in connection with large industrial areas and megacities with high local emissions (e.g. Zhang et al., 2012). Air pollution episodes can, however, also affect smaller cities (e.g. Junk et al., 2003; Schicker and Seibert, 2009; Grange et al., 2013). In areas with comparatively low emissions, slow removal and long accumulation of locally emitted pollutants are usually responsible for the occurrence of air pollution episodes. For cities in mountainous 
areas, this can be caused either by a local circulation trapping the pollutants or by local stagnation within the surrounding mountains (Rotach et al., 2004; Steyn et al., 2013). The most prominent examples of such local stagnation are typically observed in stably stratified cold air pools trapped in valleys and other orographic depressions (e.g. Reeves and Stensrud, 2009; Hoch et al., 2011; Sheridan et al., 2014; Hughes et al., 2015).

The local trapping and stagnation conditions are notoriously difficult to study, as their interaction with the controlling large-scale circulation in the free atmosphere can be complex and nonlinear (e.g. Whiteman and Doran, 1993; Zängl, 2003). Interactions within the cold air pools can be further complicated by other local dynamic effects, such as breeze-like circulations (e.g. Lareau et al., 2013) or up- and down-slope winds (Fernando, 2010). This complexity challenges numerical weather prediction (NWP) models, which often cannot properly resolve and hence predict air pollution episodes, in particular those developing during the periods with strong stable stratification in the lower atmosphere and mountainous terrain (e.g. Berge et al., 2002; Fay and Neunhäuserer, 2006; Baklanov et al., 2011). Thus, the problem could be partially related to an insufficient spatial model resolution with respect to the relevant topographic features. But partially, it should be also related to the breakdown of inadequate turbulent mixing schemes for the atmospheric stably stratified boundary layer (Atlaskin and Vihma, 2012; Fernando and Weil, 2010; Mahrt, 2014; Zilitinkevich et al., 2015). These and other inaccuracies in the air quality assessment and modelling motivated the Pan-Eurasian Experiment (PEEX) community to include air pollution in the stably stratified boundary layers in the list of research priorities addressing the environmental and socio-economic challenges of the northern high latitudes (Lappalainen et al., 2016).

Large-eddy simulations (LESs) can resolve much of the relevant turbulence dynamics. The computational costs of high-resolution LESs over larger urban areas are, however, too high to be used operationally. While this might change in the near future (Schalkwijk et al., 2015), LES models are today mostly used for the simulation of specific scenarios or for process studies in order to gain a deeper understanding of the flow features at hand (Bergot et al., 2015; Esau, 2007, 2012; Patnaik and Boris, 2010). Increased local knowledge and general understanding of the relevant processes (e.g. Glazunov et al., 2016) can then help the forecasters to improve air quality predictions based on NWP models, as suggested by Steyn et al. (2013).

LES models are more and more used for the study of the air flow in model domains with realistic urban topography. One could name a few relevant urban studies. For example, Letzel et al. (2008) and Nakayama et al. (2012) simulated the flow on the neighbourhood-scale in Tokyo, Japan. Esau (2012) studied the dispersion of a passive tracer over central Paris, France. Keck et al. (2014) used an LES model for an assessment of the effect of a new densely built-up ar- tificial island in Macau, China. Park et al. (2015a, b) studied the street-level ventilation in Seoul, South Korea.

So far however, most of the published studies were conducted under neutral or slightly convective conditions. While the use of LES for the simulation of the stably stratified conditions has become more common in the recent years, only few studies run LESs of the urban stably stratified atmospheric boundary layer (ABL). Cheng et al. (2010) and Tomas et al. (2016) studied a stratified flow over arrays of surface mounted boxes. Xie et al. (2013) studied the effect of stable stratification on the dispersion conditions over a kilometre-scale domain in London. Chen et al. (2011) developed a coupled modelling system, which includes the mesoscale Weather Research and Forecasting (WRF) and LES models, and Wyszogrodzki et al. (2012) applied this modelling system to study convective and weakly stably stratified flows over a kilometre-scale domain in Oklahoma City. A review of urban ABL modelling in a number of different settings was published by Barlow (2014). Nevertheless, to our knowledge there are no high-resolution studies devoted to the simulation of the stably stratified urban ABL in a domain relevant to urban management and decision-making.

This study is intended to reduce the above-mentioned knowledge gap. It is based on a new set of fine-resolution LESs of the topography- and breeze-induced circulation for the realistic topography of a larger part of Bergen, Norway. Strongly stable stratification of the lowermost atmospheric layers has been recognized as a precursor for the accumulation of air pollutants and subsequent air quality hazards in Bergen. The city centre is embedded in a coastal valley ending at a large sea inlet called Byfjorden. Periods of high air pollution are observed during persistent temperature inversions, indicating the stably stratified conditions inside the valley (Wolf et al., 2014; Wolf and Esau, 2014). Observations of the typical circulation and temperature conditions above and within the valley are used to drive the LES runs. We would like to focus on the interaction between the largescale circulation above the valley, modified by the local topography, and a local land breeze between the cold land and the warm fjord under inversion conditions. This interaction is leading to the strongest stagnation and hence accumulation of pollutants inside the valley. The simulations should further serve as a proof of concept for the added value of high-resolution LESs for the analysis of urban air pollution dispersion in complex mountain terrain.

This study is structured as follows. In Sect. 2 we will present an observational dataset that motivated this work. In Sect. 3 we will outline the applied methodology, and the results will be presented in Sect. 4 and summarized and discussed in the last section. 

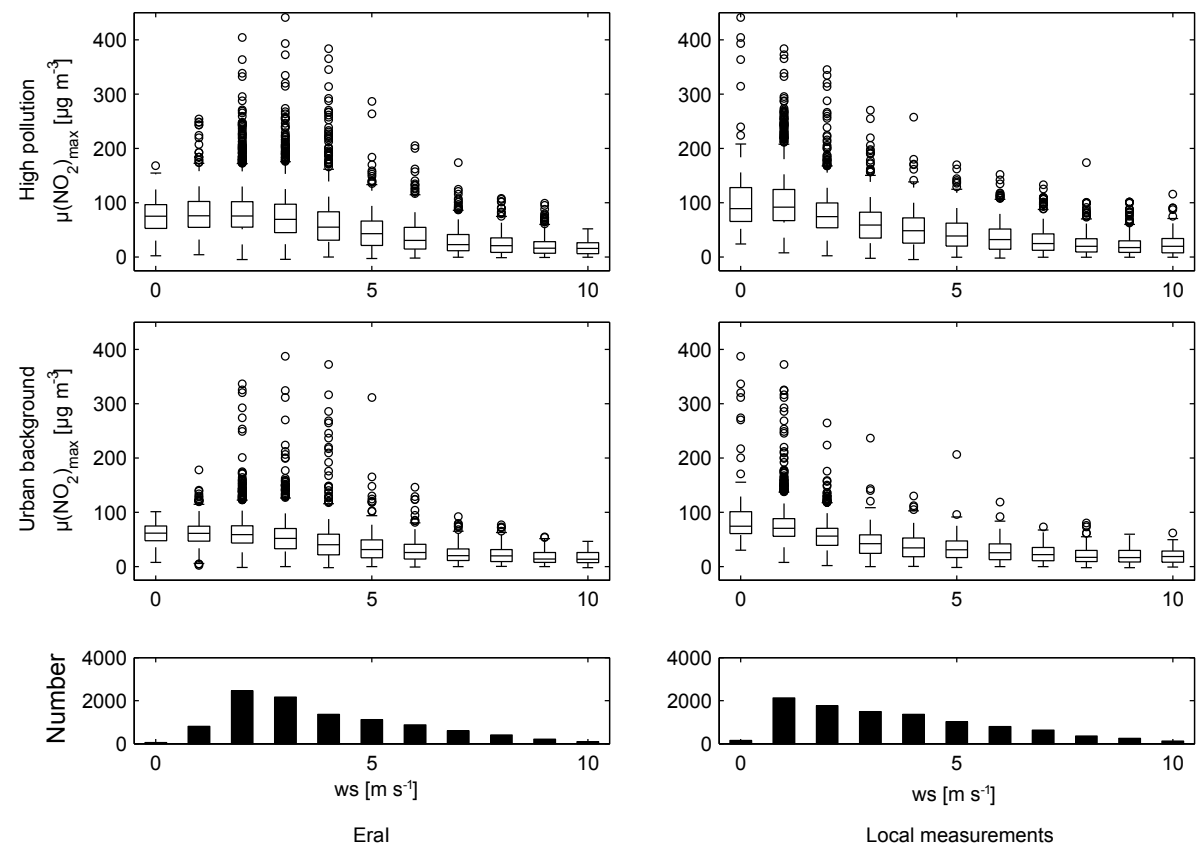

Figure 1. $\mathrm{NO}_{2}$ concentrations at the two air quality reference stations in Bergen against the $10 \mathrm{~m}$ wind speeds (ws) over the Bergen Valley from EraI and from local measurements inside the valley between 2003 and 2013. EraI data are available every $3 \mathrm{~h}$. $\mathrm{NO}_{2}$ concentrations and the local measured winds represent hourly means. The $\mathrm{NO}_{2}$ concentrations are the 3-hourly maxima and the local wind data are the 3-hourly means around the $3 \mathrm{~h}$ time steps. Only wintertime data (November-February) are included. The edges of the boxes are the 25th and 75th percentiles. Lines inside the boxes show the median. The maximum whisker length is 1.5 times the distance between the 25 th and 75th percentiles or the maxima and minima of the data. Outliers with higher or lower concentration values than that are shown as circles. The lower panels show the number of simultaneously valid wind and pollution measurements within each wind-speed bin.

\section{Observational perspective on air pollution in coastal cities}

For coastal cities, land-sea breeze circulations can have a strong impact on the local circulation. This can lead to a transport of pollutants from high emission areas onwards to inhabited areas (Gariazzo et al., 2007) or a closed recirculation and hence accumulation of pollutants (Crosman and Horel, 2016; Lo et al., 2006; Rimetz-Planchon et al., 2008). Most of these works have in common that the background circulation reduces the relevance of the local effects (Crosman and Horel, 2010). For coastal mountain cities there is, however, also the possibility of an interaction between local circulations such as local breezes and cold air pools (Holmer et al., 1999; Lareau et al., 2013). These local circulations can be either dominating the local circulation forced by the largescale flow or interacting with it. Both can lead to a deviation from the usual situation of a weaker background flow leading to higher local accumulation of air pollutants.

Figure 1 illustrates this based on the distribution of the $\mathrm{NO}_{2}$ concentrations against wind speeds above and inside the Bergen Valley. Wind speeds inside the valley are measured on a mast on top of the Geophysical Institute (GFI; see Sect. 3.1) at $12 \mathrm{~m}$ above the roof (approximately $50 \mathrm{~m}$ height). The air flow at this height is unobstructed by other buildings. The measurements should therefore be representative of the air flow in the middle of the valley. Qualitycontrolled hourly data for the entire period between 2003 and 2013 were readily available online (Norwegian Meteorological Institute, 2016). The expected logarithmic decrease of the $\mathrm{NO}_{2}$ concentrations with increasing wind speeds inside the valley is visible for both an urban background (UB) and high-pollution (HP) reference station (compare to Sect. 3.1; data downloaded from Norwegian Institute for Air Research, 2016). For the surface $(10 \mathrm{~m})$ wind speeds from the ERAInterim (EraI) reanalysis product, however, such a clear decrease does not exist. Due to the low resolution of EraI, the $10 \mathrm{~m}$ winds are not influenced by small-scale topographic features such as the Bergen Valley. They should therefore represent the large-scale flow that is only modified by the Norwegian topographic features on scales larger than a few tens of kilometres. The maximum $\mathrm{NO}_{2}$ air pollution is found for wind speeds around $3 \mathrm{~m} \mathrm{~s}^{-1}$. This maximum in the concentrations at some non-zero background wind speed suggests an interaction of the background flow with a local forcing under the cold air pool conditions. Some combination of all three circulation features then leads to a maximum stagnation over the valley bottom.

Thus, we observe that any air quality prediction based on meteorological fields from models that are not resolving this 
local forcing could fail to resolve the highest local air pollution concentrations. We assume that the most relevant local forcing in the Bergen Valley is the breeze circulation caused by the temperature difference through the land-sea interface. The relevance of the interplay between the larger-scale circulation, the local topography, and the local forcing is therefore assessed in this study.

\section{Model experiments}

\subsection{Geographical description of the simulation domain}

Bergen, Norway, is located at the Norwegian west coast $\left(60.4^{\circ} \mathrm{N}, 5.3^{\circ} \mathrm{E}\right)$. The central part of the city is located in a curved valley with a minimum width at the valley base of approximately $1 \mathrm{~km}$ (Fig. 2). The surrounding mountain tops are between 344 and $642 \mathrm{~m}$ high. Inside the valley there are a number of water bodies aside the fjord. Only the largest ones close to the city centre are explicitly treated in this study.

Since 2003 two measurement stations have been monitoring the street-level ( $2 \mathrm{~m}$ above surface) air quality in the Bergen Valley: a high-pollution reference station that is located nearby one of the busiest crossroads in the city and an urban background reference station. The valley favours frequent wintertime ground-based temperature inversions (Wolf et al., 2014), leading to the exceedances of air quality thresholds for $\mathrm{NO}_{2}$ and $\mathrm{PM}_{2.5}$, especially in areas with high traffic. In contrast to some cold air pools in large valleys (e.g. Zhong et al., 2001), the cold air pools connected to air quality hazards in the Bergen Valley are caused by ground-based temperature inversions. They cannot exist without persistent long-wave (LW) radiative cooling such as during fairweather events in wintertime with little to no solar insolation and clouds. Temperature inversions in the Bergen Valley usually appear in connection with a specific circulation pattern both inside and outside the valley. Wolf et al. (2014) analysed the $10 \mathrm{~min}$ wind measurements from an automatic meteorological station (AMS) on top of GFI together with measurements of the vertical temperature profile above GFI. The study identified almost exclusively down-valley winds during measurements with temperature inversions, while during measurements without temperature inversions both upvalley and down-valley channelled flows existed. This, together with the previously mentioned south-easterly background flow above the Bergen Valley during high air pollution events, gave reason to assume that the preferred wind direction inside the valley simply follows the large-scale wind direction above. In this case the mountain to the south-east of the Bergen Valley would shelter the valley. This is, however, too simplistic a picture since the sheltering mountains would represent a backward-facing step for the approaching winds, which can lead to very complicated flow regimes (Mohamad and Viskanta, 1995).

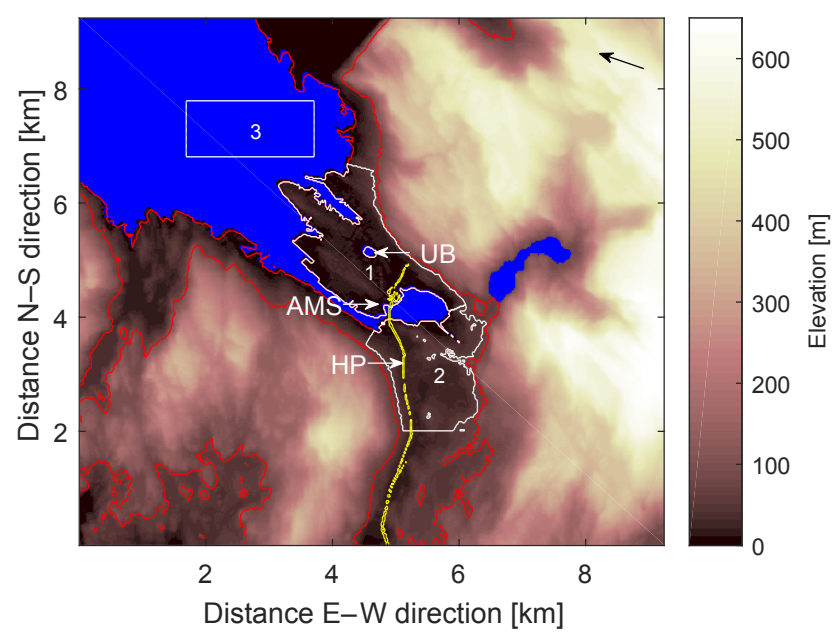

Figure 2. Topographic map of the Bergen area represented in the model simulations. Blue colour indicates water. The white contour line marks the areas 1 and 2 selected for averaging of the wind and passive tracer concentration. The red contour line marks the area of passive tracer emissions in most of the experiments. Both lines are overlapping along the coast. The yellow line represents the main street along the valley, eventually disappearing into a tunnel after having crossed the valley. White arrows indicate the positions of the wind measurements (AMS), and the urban background (UB) and high pollution (HP) reference stations for $\mathrm{NO}_{2}$ air pollution. The area for averaging of the $2 \mathrm{~m}$ temperature over the fjord in Table 1 is marked as area 3; averaging of the $2 \mathrm{~m}$ temperature over the city centre is done separately over areas 1 and 2 . The black arrow in the upper right corner indicates the $110^{\circ}$ geostrophic wind direction used for the simulations.

During persistent wintertime temperature inversions in the Bergen Valley, the local lakes often freeze over. The fjord, however, remains mostly ice-free, causing large temperature contrasts between the relatively warm fjord surface and the cold land surface, possibly leading to the local breeze circulation inside the valley. The large water body roughly in the middle of the domain is connected to the fjord only though a narrow channel. It therefore has a lower salinity than the fjord and tends to freeze over with a thin layer of ice during persistent temperature inversion episodes. It is consequently treated as a lake later on.

\subsection{The model}

In the experiments for this study we used the Parallelized Large-Eddy Simulation Model (PALM) for atmospheric and oceanic flows, (Maronga et al., 2015; Raasch and Schröter, 2001). PALM solves the finite-difference numerical realization of the non-hydrostatic, filtered, incompressible NavierStokes equations in their Boussinesq approximated form. The model employs a 1.5-order closure using a subgrid-scale TKE balance equation (Deardorff, 1980; Moeng and Wyngaard, 1988; Saiki et al., 2000). Advection terms are computed using the fifth-order scheme after Wicker and Ska- 
marock (2002). The model time step is adjusted dynamically. The incompressibility condition is satisfied with a predictorcorrector method, using the Temperton fast Fourier transformation to solve the Poisson pressure equation. Spatial discretization is done on an Arakawa type $\mathrm{C}$ grid. Topographic features of the urban area are simplified as ground-mounted boxes. Topographic input needs to be specified as a separate input file that fits the horizontal model grid. Vertical discretization of the surface height onto the model grid is done automatically by the model.

\subsection{Modifications to the PALM code}

PALM runs either with Neumann surface temperature boundary condition (BC), where the kinematic surface heat flux $\left(H_{\mathrm{S}}\right)$ is prescribed, or with Dirichlet $\mathrm{BC}$, where the surface temperature $\left(T_{\mathrm{S}}\right)$ is fixed. In the case of the Dirichlet $\mathrm{BC}$, heat fluxes on horizontal surfaces are calculated by assuming a Prandtl layer. In order to be able to simulate the potential breeze effect in the valley, we added the possibility to use mixed Dirichlet and Neumann BCs in the model. Consistent with the large heat capacity of water, we kept $T_{\mathrm{S}}$ constant over the water-covered parts of the computational domain. This allows for the development of the typical pattern of organized turbulence over the water surface, as it has been repeatedly found for breeze circulations, e.g. induced by arctic leads (Esau, 2007; Lüpkes et al., 2008). Over the land surface, we kept $H_{\mathrm{s}}$ constant in order to represent the effect of LW radiative cooling. While specifying negative $H_{\mathrm{s}}$ can be problematic for LES studies (Basu et al., 2008), it was necessary here to incorporate the inhomogeneities in surface temperature due to the large differences in surface elevation and the land-sea interface. A description of our modifications to PALM for the usage of heterogeneous surface boundary conditions is given in the Supplement. In order to be able to study the dispersion of pollutants from different emission sources, we used the same approach for reading heterogeneous fields for the surface flux of a passive tracer $F_{\mathrm{s}}$. To avoid unphysical recycling of the passive tracer due to periodic boundary conditions, we set the passive tracer to 0 at the lateral boundaries of the computational domain.

\subsection{Domain}

The simulations are done for the realistic topography of the city of Bergen, Norway. For this, we received laser scanning data from the municipality of Bergen for a $5 \mathrm{~km}$ square around Bergen city hall. In the choice of the final domain size, we tried to include the mountains directly surrounding the inner part of the city, while attempting to keep the computational domain as small as possible. At the lateral boundaries, we used periodic BC. The Bergen Valley is open towards the north-west and south-west (not visible in Fig. 2 due to the small domain used for the simulations). In order to allow for a more realistic free flow along the valley axis, we created an artificial channel at the northern end of the domain. While necessary in order to avoid an unnatural stagnation in the southern part of the valley, this channel might also alter the circulation over the fjord at the northern boundary of the computational domain. For future studies this should be avoided by using a larger north-south extent of the domain. At the lateral boundaries we used a $1000 \mathrm{~m}$ wide buffer zone, both in the $x$ and $y$ directions. In this buffer zone, surface elevations are linearly interpolated in order to guarantee a smooth transition through the periodic boundaries.

Polygons of all water bodies in Bergen were provided by Bergen municipality. From this, we produced the input files for the areas with constant $H_{\mathrm{S}}$ over land and constant $T_{\mathrm{S}}$ for grid boxes that were covered by more than $50 \%$ of water. As a simplification we ignored most freshwater lakes. The final domain consists of $1024 \times 1024$ grid nodes in the horizontal $x$ and $y$ directions including the buffer zones, and 128 levels in the vertical $z$ direction. The model resolution is $10 \mathrm{~m}$ for each coordinate axis in the lower $750 \mathrm{~m}$ of the computational domain. Above $750 \mathrm{~m}$ the grid is vertically stretched by $1 \%$ for each additional grid level. The total domain size is $L_{x}=L_{y}=10240 \mathrm{~m}$ and $L_{z}=1451 \mathrm{~m}-$ well above the highest mountaintop at $650 \mathrm{~m}$. We smoothed the topography with a running mean filter over three grid cells in both lateral directions.

The extent of the fjord in this setup is roughly $4 \mathrm{~km}$ in the $\mathrm{E}-\mathrm{W}$ direction and $3 \mathrm{~km}$ in the $\mathrm{N}-\mathrm{S}$ direction. The western boundary of the fjord is representative for the location of a large island closing the fjord, except for a $700 \mathrm{~m}$ wide passage. To the north, the fjord extends in reality much further than in our setup. The artificially set northern boundary therefore reduces the fjord's extent. A comparison to Esau (2007) shows, however, that $2-4 \mathrm{~km}$ is the size where the drag of air from warm arctic leads stagnates at its maximum, meaning that the convergence in the $\mathrm{N}-\mathrm{S}$ direction should be sufficient to cause a realistic drag of air in the valley.

It should be noted that a $10 \mathrm{~m}$ resolution is clearly too coarse to resolve the circulation in street canyons (Letzel et al., 2008, 2012). It is also too coarse for the simulation of the stably stratified ABL over flat and homogeneous surfaces (Beare et al., 2006; Mason and Derbyshire, 1990). The focus of this study, however, is on the effect of the larger topographic features (valley width above $1 \mathrm{~km}$ ) and the convection over the fjord on the circulation within the valley. Both forcings should be sufficiently reproduced with the chosen resolution. An analysis of the kinematic heat fluxes of sensitivity test simulations with 5 and $20 \mathrm{~m}$ resolutions in addition to the $10 \mathrm{~m}$ resolution chosen here confirmed this.

The smoothing to a $10 \mathrm{~m}$ resolution from the laserscanning-point clouds implicitly includes a surface displacement in the case of strongly variable topography. No further displacement height is included in the simulations as the non-resolved roughness elements are small compared to the resolved mountain topography. The unresolved roughness length in LESs of urban areas and strong topography 
is an interesting question itself but goes beyond the scope of the work presented here. We have therefore chosen a constant roughness length across the entire domain of $0.5 \mathrm{~m}$. A test with roughness length of $2 \mathrm{~m}$ showed qualitatively similar results with some quantitative differences. We therefore assume the roughness length to be a relevant parameter that should be studied further but assume the overall conclusions of this publication not to be dependent on it.

\subsection{Numerical experiments}

The numerical experiments are listed in Table 1. All experiments share a common basic setup: the latitude was $60.38^{\circ} \mathrm{N}$, corresponding to Bergen. At initialization, the surface potential temperature was $273.15 \mathrm{~K}$ with constant potential temperature up to $650 \mathrm{~m}$, and a constant potential temperature gradient of $5.5 \times 10^{-3} \mathrm{~K} \mathrm{~m}^{-1}$ above that level. This is the mean potential temperature gradient above Bergen during high-pollution cases derived from the EraI data set. $H_{\mathrm{S}}$ over land was chosen as $-0.025 \mathrm{~K} \mathrm{~m} \mathrm{~s}^{-1}$, corresponding to approximately $25 \mathrm{~W} \mathrm{~m}^{-2}$. This is in agreement with heat fluxes found from observational studies (Brümmer and Schultze, 2015; Nordbo et al., 2012). In addition to the cases with mixed BC, we also simulated a test case with a constant $H_{\mathrm{S}}$ of $0 \mathrm{~K} \mathrm{~m} \mathrm{~s}^{-1}$ over the entire domain, representing a situation with neutral stratification.

All simulations were run for $12 \mathrm{~h}$ in order to reach a quasiequilibrium state. During this time we kept the surface potential temperature over most water bodies at $273.15 \mathrm{~K}$. The surface potential temperature of the elongated lake in the northeast of the Bergen Valley was $273.89 \mathrm{~K}$. This is the potential temperature corresponding to a temperature of $0{ }^{\circ} \mathrm{C}$ at the height of the lake surface (approximately $75 \mathrm{~m}$ ). The temperature chosen over the fjord is given in Table 1 for each simulation. For cases 1 through 12 we included emission of a passive tracer over the entire urban area into the model simulations. As emission rate we chose an arbitrary value of $1\left(\mathrm{~kg} \mathrm{~m}^{-2} \mathrm{~s}^{-1}\right)$. In order to mimic the actual extent of the build-up city area, we only allowed for emissions over landcovered grid cells with surface elevation below $70 \mathrm{~m}$ in the original input file. For the last three cases we used the same emission strength, but only for the area covered by the largest street in the valley (see Fig. 1). The exact geographic location of this street was provided to us by Bergen municipality.

PALM simulations are usually driven with an imposed geostrophic wind profile. For the geostrophic winds in our model experiments we used three different scenarios, illustrated in Fig. 3. The profile with the lowest wind speeds follows the mean of the wind-speed profiles from EraI above Bergen during days with high- $\mathrm{NO}_{2}$ air pollution (at least one hourly mean measurement exceeding $200 \mathrm{\mu g} \mathrm{m}^{-3}$ at the hightraffic reference station). Because of the varying height of the EraI model levels, we linearly interpolated the wind profiles between the nearest model levels to 410, 450, 600, 800, 1000, 1200 , and $2000 \mathrm{~m}$ height before averaging. Since EraI has a
Table 1. Model simulations.

\begin{tabular}{|c|c|c|c|c|c|}
\hline Case & $\begin{array}{c}\text { Wind } \\
\text { scenario }\end{array}$ & $\begin{array}{c}\theta_{\text {fjord }} \\
(\mathrm{K})\end{array}$ & $\begin{array}{c}T_{2 \mathrm{~m}} \\
\text { (fjord) } \\
(\mathrm{K})^{\mathrm{b}}\end{array}$ & $\begin{array}{c}T_{2 \mathrm{~m}} \\
(\text { area 1) } \\
(\mathrm{K})^{\mathrm{b}}\end{array}$ & $\begin{array}{c}T_{2 \mathrm{~m}} \\
(\operatorname{area} 2) \\
(\mathrm{K})^{\mathrm{b}}\end{array}$ \\
\hline Case $0^{\mathrm{a}}$ & sc 1 & - & - & - & - \\
\hline Case 1 & sc 1 & 270.7 & 271.5 & 269.8 & 268.0 \\
\hline Case 2 & sc 1 & 273.2 & 273.6 & 271.3 & 269.1 \\
\hline Case 3 & sc 1 & 275.7 & 275.4 & 272.0 & 270.1 \\
\hline Case 4 & sc 1 & 278.2 & 277.4 & 273.0 & 271.6 \\
\hline Case 5 & sc 2 & 273.2 & 273.7 & 271.5 & 269.0 \\
\hline Case 6 & sc 2 & 275.7 & 275.4 & 272.2 & 270.8 \\
\hline Case 7 & sc 2 & 278.2 & 277.4 & 273.3 & 272.8 \\
\hline Case 8 & sc 2 & 280.7 & 279.1 & 274.4 & 273.3 \\
\hline Case 9 & sc 3 & 273.2 & 273.7 & 271.7 & 269.8 \\
\hline Case 10 & sc 3 & 275.7 & 275.5 & 272.5 & 271.0 \\
\hline Case 11 & sc 3 & 278.2 & 277.3 & 273.5 & 272.4 \\
\hline Case 12 & sc 3 & 280.7 & 279.1 & 275.1 & 275.2 \\
\hline Case $13^{c}$ & sc 3 & 273.2 & 273.7 & 271.7 & 269.8 \\
\hline Case $14^{\mathrm{c}}$ & sc 3 & 275.7 & 275.5 & 272.5 & 271.1 \\
\hline Case $15^{\mathrm{c}}$ & sc 3 & 278.2 & 277.3 & 273.5 & 272.4 \\
\hline
\end{tabular}

a Simulation with Neumann $\mathrm{BC}$ and $H_{\mathrm{S}}=0 \mathrm{~K} \mathrm{~m} \mathrm{~s}^{-1}$ over entire domain.

${ }^{\mathrm{b}}$ Calculated from a linear extrapolation of the potential temperature gradient between the two lowest grid points above topography. Absolute temperature calculated with reference pressure $1000 \mathrm{hPa}$. The mean temperatures over land contain areas up to $70 \mathrm{~m}$ surface elevation. In inversion conditions this results in a higher mean temperature than only for the lowest areas. ${ }^{\mathrm{c}}$ Emissions only from the largest street in the Bergen Valley.

rather low resolution, the lowest grid layer over Bergen is at approximately $410 \mathrm{~m}$, depending on surface pressure. In 4 out of the total 45 high-pollution days in the measurement record, the lowest model layer was centred above $410 \mathrm{~m}$. For these cases, no wind speed was available at the $410 \mathrm{~m}$ height. As the lowest point in the PALM domain is the sea surface, it was, however, necessary to specify a wind speed below $410 \mathrm{~m}$ height. We chose to use the wind speed from $410 \mathrm{~m}$ in EraI at $100 \mathrm{~m}$ height in our PALM simulations and $0 \mathrm{~m} \mathrm{~s}^{-1}$ wind speed at sea level. The mean wind direction profile during all high-pollution cases changed from $100^{\circ}$ at the lowest levels to $120^{\circ}$ higher up. For simplicity, we kept the wind direction constant at $110^{\circ}$. The two higher wind-speed scenarios follow vertical wind-speed gradients of 1.5 and 2 times the mean gradient for all height levels above $100 \mathrm{~m}$.

\subsection{ERA-Interim data}

EraI data are available from the ECMWF archive (Dee et al., 2011; ECMWF, 2016). The resolution of EraI (T255) is too coarse to resolve any of the relevant features of the Bergen Valley. We therefore used the EraI wind speed and direction for the specification of the background winds in PALM. We downloaded data at a horizontally interpolated grid of $0.25^{\circ}$ resolution and used the mean over the two grid boxes centred at $5.5^{\circ} \mathrm{E}, 60.25^{\circ} \mathrm{N}$ and $5.5^{\circ} \mathrm{E}, 60.5^{\circ} \mathrm{N}$ that represented best the location of Bergen. For calculating the daily mean fields, we used EraI data at a 3-hourly resolution from a 


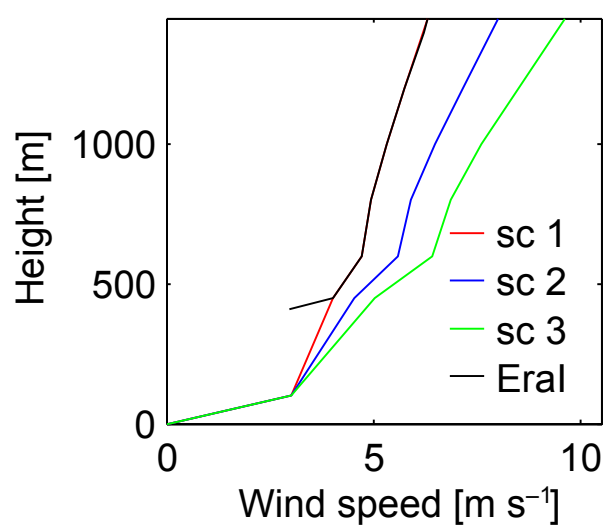

Figure 3. Geostrophic wind profile scenarios used for the model simulations. The black line shows the mean EraI wind profile over the Bergen Valley for all high-pollution cases (they start only at $410 \mathrm{~m}$ due to the low horizontal resolution of EraI). Above $450 \mathrm{~m}$ the red and black lines are overlapping.

combination of the analysis steps at 06:00, 12:00, 18:00, and 00:00 UTC plus the 3 and $9 \mathrm{~h}$ lead time forecasts of the 00:00 and 12:00 UTC analyses.

\section{Results}

\subsection{Main features of the Bergen Valley circulation}

The setup used here was chosen to study the potential effect of the breeze-induced circulation on the dispersion of pollutants in the Bergen Valley under the conditions of typical wintertime temperature inversions. Here we will highlight the most relevant features and briefly compare them to the results of the observational study conducted by Wolf et al. (2014) in order to better understand the circulation in the valley. By this we will also investigate the potential and limitations of the chosen setup for the proposed flow interactions. We use case 3 with the mean wind-speed profile during all high-air-pollution cases as a baseline. The fjord temperature of $2.5^{\circ} \mathrm{C}$ should be realistic for typical persistent wintertime temperature inversions.

After $12 \mathrm{~h}$ all simulations are in quasi-steady-state conditions. The resulting $2 \mathrm{~m}$ temperatures over the fjord and area 1 and 2 of the city are given in Table 1 . The $2 \mathrm{~m}$ temperature is calculated as a linear extrapolation of the temperature curve between the first two vertical grid levels above the topography at 5 and $15 \mathrm{~m}$. While the absolute temperatures over the different areas are irrelevant for this study, their differences are an indicator for the breeze circulation. By design, the difference between the air temperatures over the fjord and the temperatures over the city are increasing with increasing fjord surface temperatures, consequently applying the forcing for a breeze circulation. In addition, the air temperature over the interior part of the valley is, except for

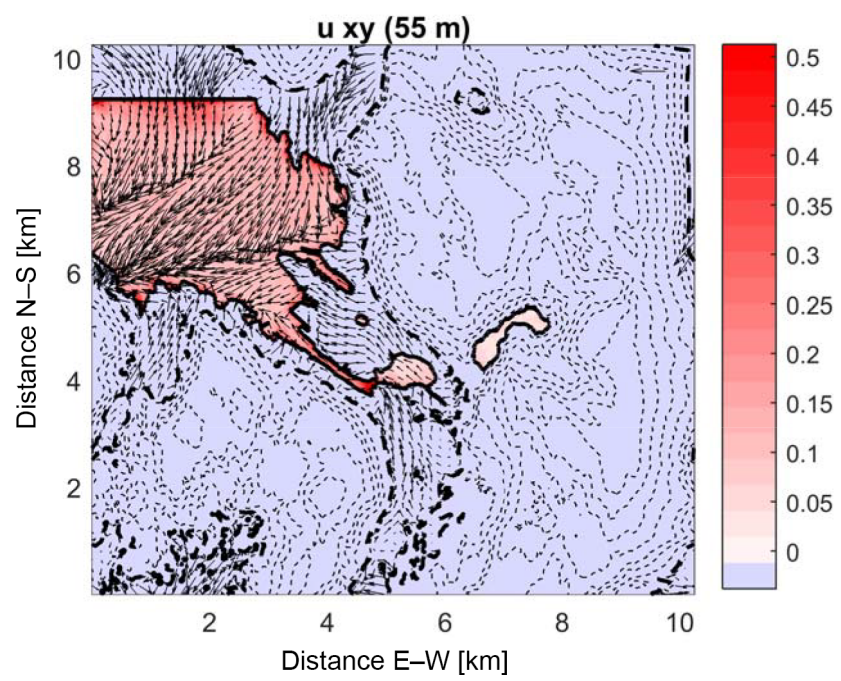

Figure 4. The $55 \mathrm{~m}$ wind field from case 3 together with $H_{\mathrm{S}}$ $\left(\mathrm{Km} \mathrm{s}^{-1}\right)$. The figure shows the mean fields over the last $15 \mathrm{~min}$ of the $12 \mathrm{~h}$ simulation time. Wind vectors point into the flow direction. The wind vector in the upper right corner indicates the scale of the wind vector length. It shows a wind speed of $3 \mathrm{~m} \mathrm{~s}^{-1}$. The $55 \mathrm{~m}$ topographic line is indicated by the thick black dashed line. The water-land interface is shown by the thick solid line.

case 12 , lower than the air temperature over the outer part of the valley. This could exert another breeze-like forcing between these two parts of the valley. The dependence of the breeze effect on the prescribed fjord surface temperature decreases over time. This allows simulations based on the same wind profile to converge. The reason is that, over land, the heat flux is fixed instead of the absolute temperature. The land surface temperature therefore slowly adapts to the fjord surface temperature due to the advection of relatively warmer air from the recirculation within the valley and the periodic BC. The latter is caused by an imbalance in the $H_{\mathrm{s}}$ across the entire domain through different fjord surface temperatures. Neglecting the constant temperature over the smaller water bodies, after very long simulation times in principle the atmosphere should reach an equilibrium circulation that is equal for all different fjord surface temperature scenarios. How fast this equilibrium is established depends on the total volume of the computational domain and the land and sea fractions. No convergence was visible for any of the windspeed scenarios simulated here.

Figure 4 shows the wind field from case 3 on the vertical level centred at $55 \mathrm{~m}$ together with $H_{\mathrm{s}}$. This is the first vertical level above the AMS used in Wolf et al. (2014; marked in Fig. 2). The south-easterly, down-valley mean flow above GFI is reproduced in our simulation. The mean $H_{\mathrm{s}}$ over all water bodies is $143 \mathrm{~W} \mathrm{~m}^{-2}$. Maximum values of up to $1000 \mathrm{~W} \mathrm{~m}^{-2}$ for a few grid nodes are located in direct proximity to the coast in areas with the strongest seaward flow, as a result of the temperature contrast between the land and the 

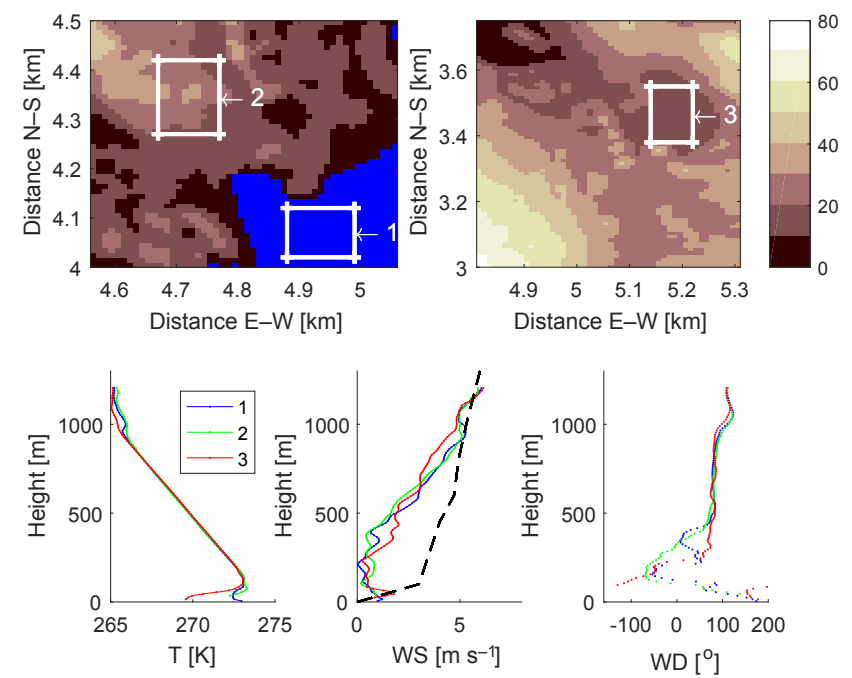

Figure 5. Vertical profiles for temperature and wind speed and wind direction (lower panels) at three locations in the Bergen Valley (marked in the upper panels). The figures show the 15 min mean data corresponding to case 3 presented in Fig. 4. All profiles are horizontal averages over the areas indicated in the top panels. The blue areas indicate water surface. The brown shading gives the surface elevation in metres. The AMS is located in the centre of area 2. The geostrophic wind profile for this scenario is indicated as a black line in the lower middle panel.

fjord surface. Over the fjord, $H_{\mathrm{s}}$ is not simply decreasing towards the middle of the fjord, but reaches its minimum in the areas of flow convergence. These are, for case 3, organized in the form of two convergence lines.

Figure 5 shows local profiles of temperature, wind speed, and wind direction over and around the large water body in the middle of the valley. Area 2 in the plot is centred over GFI. The south-easterly flow is visible up to a height of $95 \mathrm{~m}$. For areas 1 and 2 there is a gradual eastwards rotation of the wind direction, likely caused by a combination of the proximity to the warm sea inlet and the local topography. Between 95 and $105 \mathrm{~m}$ height, the wind direction jumps from easterly to north-westerly before rotating back to mostly easterly wind between 300 and $400 \mathrm{~m}$. Over area 3, the wind direction remains almost constant for the lowest parts of the ABL before gradually turning to the same north-westerly wind around $300 \mathrm{~m}$.

Case 0 (Fig. 6) with missing surface temperature and heat flux heterogeneity, showed a northerly up-valley flow, both above the fjord and inside the valley. The down-valley flow at the valley bottom was absent. The up-valley flow seems to be a persistent feature of the Bergen Valley topography under the given geostrophic wind profile, to some degree balancing the south-easterly down-valley flow that is caused by the convergence over the fjord. The flow in the valley is therefore not simply following the upper-air wind distribution, but is clearly locally forced.

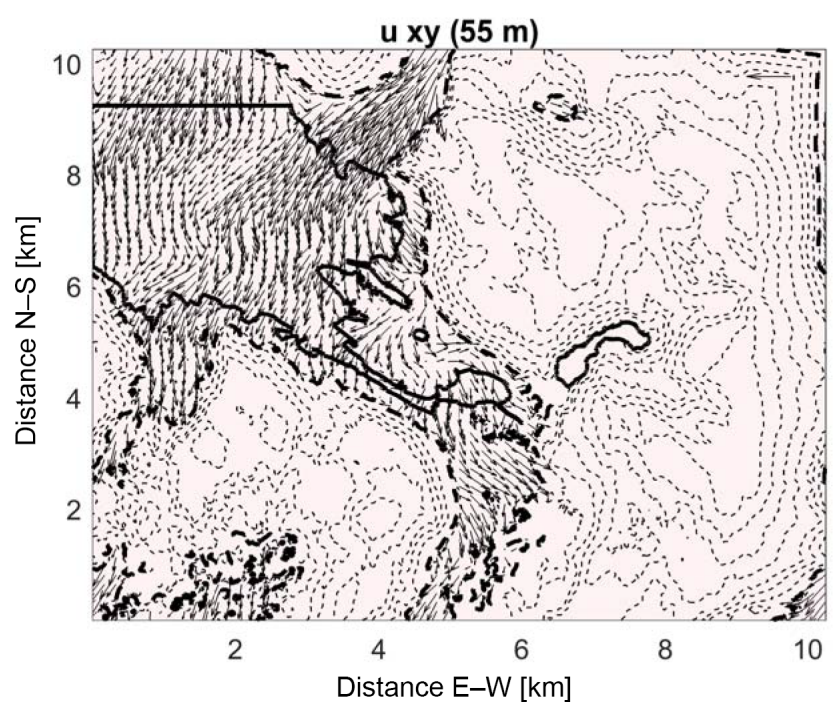

Figure 6. Same as Fig. 4 but for case 0 with Neumann BC and neutral ABL.

The north-westerly flow higher up in the valley ABL is only visible for the simulations with $270.65,273.15$, and $275.65 \mathrm{~K}$ fjord surface temperature, and for case 11 with $278.15 \mathrm{~K}$ fjord surface temperature and wind speed scenario 3 . For the simulations with higher fjord surface temperatures it is not detectable and might be masked by the southeasterly flow from the convergence over the fjord. A reverse flow above a breeze circulation is usually associated with the returning branch of the breeze circulation. An increase in the strength of the land-breeze should therefore also result in an increase of the return branch. Since this is not the case for our simulations here with increasing fjord surface temperatures indicates that the north-westerly flow higher up in the valley $\mathrm{ABL}$ is not the return branch of the land-breeze above the valley bottom.

The modelled temperature profiles in Fig. 5 show inversions up to $135 \mathrm{~m}$ height split into two separate inversions with two closely adjacent maxima for areas 1 and 2 . The top of the lowest inversion was at $75 \mathrm{~m}$ and the highest at $135 \mathrm{~m}$. For area 3, there is only one inversion ending in between the two maxima from area 1 and 2 . The results of the measurements with a passive microwave temperature profiler (MTP5HE from Attex) on the rooftop platform of GFI, presented in Wolf et al. (2014), provide the possibility for a comparison with observed inversion heights in the Bergen Valley. This instrument does not measure the vertical profiles directly above the instrument, but averages over variable horizontal distances based on the scanning angle. The measured temperature profiles are therefore rather comparable to a combination of the profiles along the horizontal measurement path, with the lower height levels including a larger horizontal distance along the measurement direction than the higher height levels. Areas 1-3 are roughly placed along the measurement 
path of the microwave radiometer, and should therefore be appropriate locations for a comparison. Due to the limited vertical resolution, the angular scanning microwave radiometer smoothes out fine structures, e.g. two closely adjacent maxima. For the other simulated cases, the inversion heights were rather similar, varying between 85 and $145 \mathrm{~m}$. The observed inversion depths in the Bergen Valley are typically ranging between 70 and $270 \mathrm{~m}$, with the majority of observations between 70 and $220 \mathrm{~m}$. Inversion episodes lasting longer than $2 \mathrm{~h}$ were on average most frequently $170 \mathrm{~m}$ deep. This indicates that our LES simulations somewhat underestimate the inversion depth. The modelled maximum inversion strength in the order of $1-3 \mathrm{~K}$ is in accordance to the observations (Wolf et al., 2014). Since the simulations presented here are rather idealized, it is likely that relevant physical processes for a more realistic representation of the inversions, such as large-scale subsidence or LW radiation divergence in the atmosphere, are not fully considered. Hoch et al. (2011) suggested a cooling of the inversion top together with a simultaneous heating of the air layers above and below. This could be a possible mechanism for further inversion growth. In addition, the temperature profile above the inversion is usually weakly stable, whereas our simulations show a well mixed profile almost to the top of the computational domain. This is caused by the application of the periodic boundary conditions in the model simulations. A nudging of the mean potential temperature gradient above the valley could reduce this problem, but is not available in the model setup we used. Improving the representation of both processes in the model is expected to result in a growth of the inversion depth. Furthermore, the flow along the valley bottom through the southern domain boundary might be overestimated in our simulations. Even though this flow feature might to some extent also exist in reality, due to the large water bodies further south in the Bergen Valley causing convergence and hence draining of air out of the city centre, this could reduce the potential for cold air pooling. Finally, the relatively low spatial resolution for the simulation of the stably stratified ABL might also negatively impact the representation of the temperature inversions in the Bergen Valley.

However, our simulations produced ground-based inversions higher than the $55 \mathrm{~m}$ model level. This means that they should be able to give us relevant information on the mean flow around the height of the AMS and below, the levels most relevant for the dispersion of locally emitted air pollutants.

\subsection{The interplay between the local and the larger-scale conditions}

The range of selected fjord surface temperatures and geostrophic wind speeds allows investigation of the interplay between the south-easterly down-valley flow, triggered by the convection over the fjord, and the north-westerly upvalley flow, forced by the flow above the valley, as well as of the effect of this interplay on the dispersion of pollutants in- side the valley. Figure 7 shows the wind field at $55 \mathrm{~m}$ height and the terrain following concentration of the surface-emitted passive tracer at $2 \mathrm{~m}$ above the ground, calculated the same way as the $2 \mathrm{~m}$ temperature before. The runs with fjord temperatures of $2.5^{\circ} \mathrm{C}$ or more show clear signs of flow convergence in the wind field over the fjord and a distinct signature of prevailing down-valley flow. For the leftmost panels with $0{ }^{\circ} \mathrm{C}$ fjord surface temperature, this convergence line is pushed all the way towards the coastline, and the flow in the exterior part of the Bergen Valley is even reversed towards an up-valley flow. For case 9, the convergence line is masked by this up-valley flow at the $55 \mathrm{~m}$ height level and is therefore only visible for the lower-level wind fields. The results show a gradual movement of the convergence line with decreasing fjord surface temperatures and increasing geostrophic wind speeds inwards towards the city centre. This is caused by a weakening of the convergence over the colder fjord. The overall flow pattern becomes more and more dominated by the up-valley recirculation, especially for the scenarios with higher wind speeds. It should, however, be mentioned that the outflow out of the artificially generated channel at the northern border of the computational domain seems to interact with the up-valley flow, enhancing it and hence pushing the convergence line towards the coast. Up-valley flows are rarely observed during temperature inversions in the valley, but they are visible in our simulations. While the coldest fjord surface temperatures considered here are also rarely observed, possibly explaining this lack of observations of the up-valley flow, it could also be artificially enhanced in our simulations by this domain boundary effect. This is, however, a persistent feature of all simulations. It might therefore shift the balance between the up-valley circulation, forced by the flow above the valley, and the breeze circulation towards lower geostrophic wind speeds and higher fjord temperatures, respectively, but is not expected to change the conclusions on the existence of the balance itself.

The effect of this on the circulation inside the valley is summarized in Fig. 8 in terms of the horizontal mean of the passive tracer concentration $2 \mathrm{~m}$ above the ground and the wind speed and direction at the $55 \mathrm{~m}$ height level and $10 \mathrm{~m}$ above the ground. For each of the given wind-speed scenarios, there is a combination of geostrophic winds and local breeze circulations, that leads to a maximum in the stagnation in the exterior part of the valley (area 1, Fig. 2). For the winds, this is visible as a plateau for the wind speed in scenarios 2 and 3, and a turning of the wind direction both at the $55 \mathrm{~m}$ height level and $10 \mathrm{~m}$ above the ground. Based on this, it can be assumed that there would be a minimum in the local wind speeds at intermediate fjord temperatures between 0 and $2.5^{\circ} \mathrm{C}$ For scenario 1 , with the lowest considered wind speeds, this balancing is not yet reached for the $10 \mathrm{~m}$ wind, while the wind at the $55 \mathrm{~m}$ height level is already rotated towards an up-valley flow. This indicates, however, that the rotation of the winds at $10 \mathrm{~m}$ above the surface would occur at fjord surface temperatures below $0{ }^{\circ} \mathrm{C}$ To investigate this fur- 

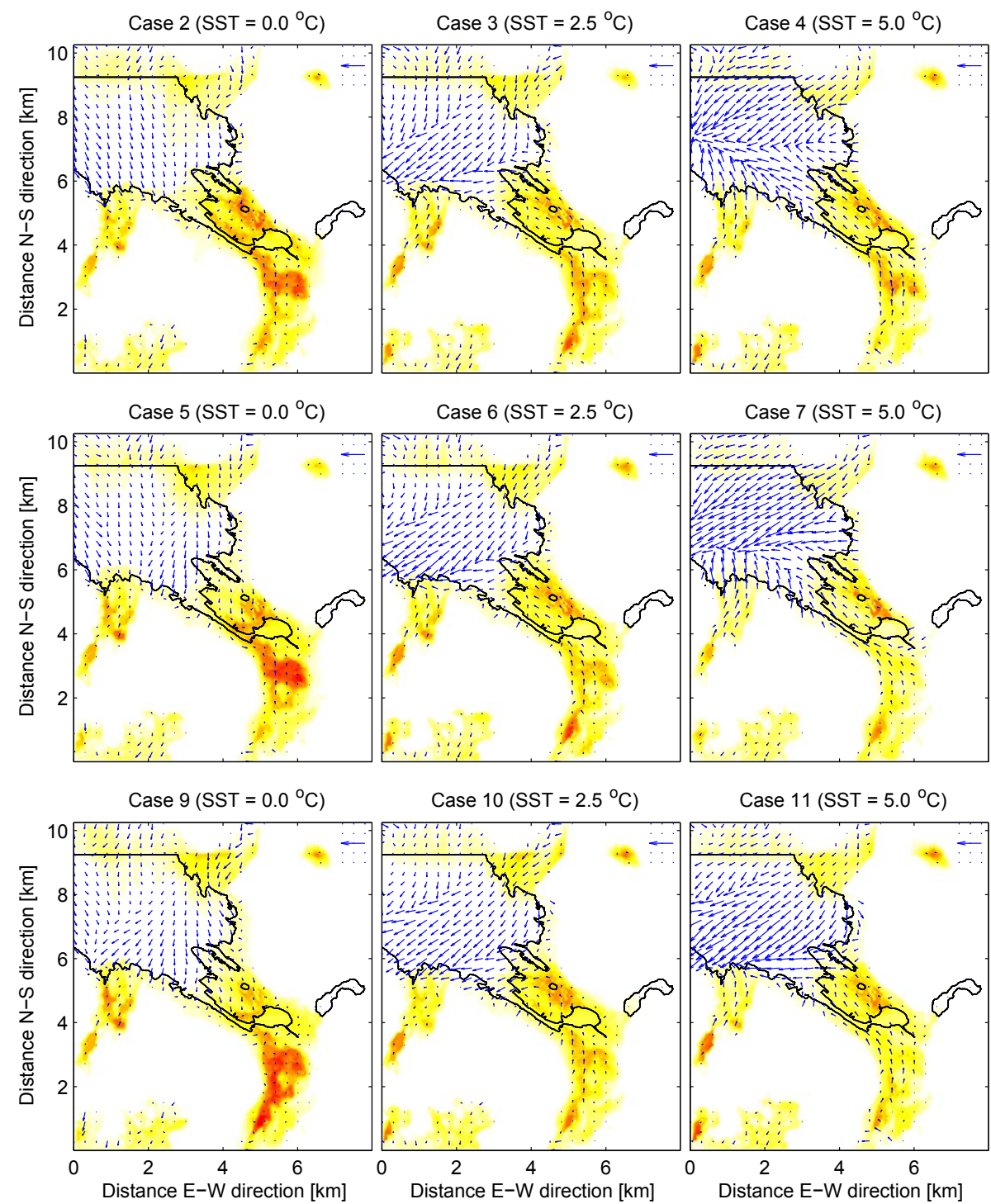

Figure 7. Wind fields at $55 \mathrm{~m}$ height and passive tracer concentration $2 \mathrm{~m}$ above the surface. The top, middle, and bottom panels show the results for wind speed scenario 1, 2, and 3, respectively. All data are means over the last four output steps of the $12 \mathrm{~h}$ simulation. Each output step is an average of $15 \mathrm{~min}$. Colour and wind-speed scales are the same in all panels. Darker colour means higher tracer concentrations. The domain is cut off at the right boundary since the topography here was mostly above $55 \mathrm{~m}$. The wind vector in the upper right corner indicates a wind speed of $5.2 \mathrm{~m} \mathrm{~s}^{-1}$. The water-land interface is shown by the black solid line.

ther we conducted a test simulation with a fjord surface temperature of $-2.5^{\circ} \mathrm{C}$. This scenario, however, led to an unrealistic maximum in convergence over all other water bodies, except for the fjord. While the absolute temperatures of the fjord and land surface are not relevant, the relative temperature differences are. During the winter the freshwater bodies are usually colder than the fjord. The constant temperature of $0^{\circ} \mathrm{C}$ over the freshwater bodies in our simulations therefore causes an unrealistic circulation in the valley at fjord surface temperatures below $0{ }^{\circ} \mathrm{C}$.

For the interior part of the valley (area 2, Fig. 2) a balance, like for the exterior part of the valley, is not visible.
The set of simulations with the lowest fjord surface temperatures of $0^{\circ} \mathrm{C}$ show both the lowest wind speeds and maximum pollutant concentrations, and no reversal of the wind direction is seen for any of the simulations at the height of the GFI AMS. One reason for this distinctly different behaviour of the interior part of the valley is the colder temperature there. The temperature difference between the $2 \mathrm{~m}$ surface air temperatures over area 1 and 2, at least for the lower fjord surface temperatures, is similar to the temperature difference between the surface air temperatures over area 3 and 1 (see Table 1 for comparison). The different land surface temperatures therefore exert an additional forcing on the air in the in- 

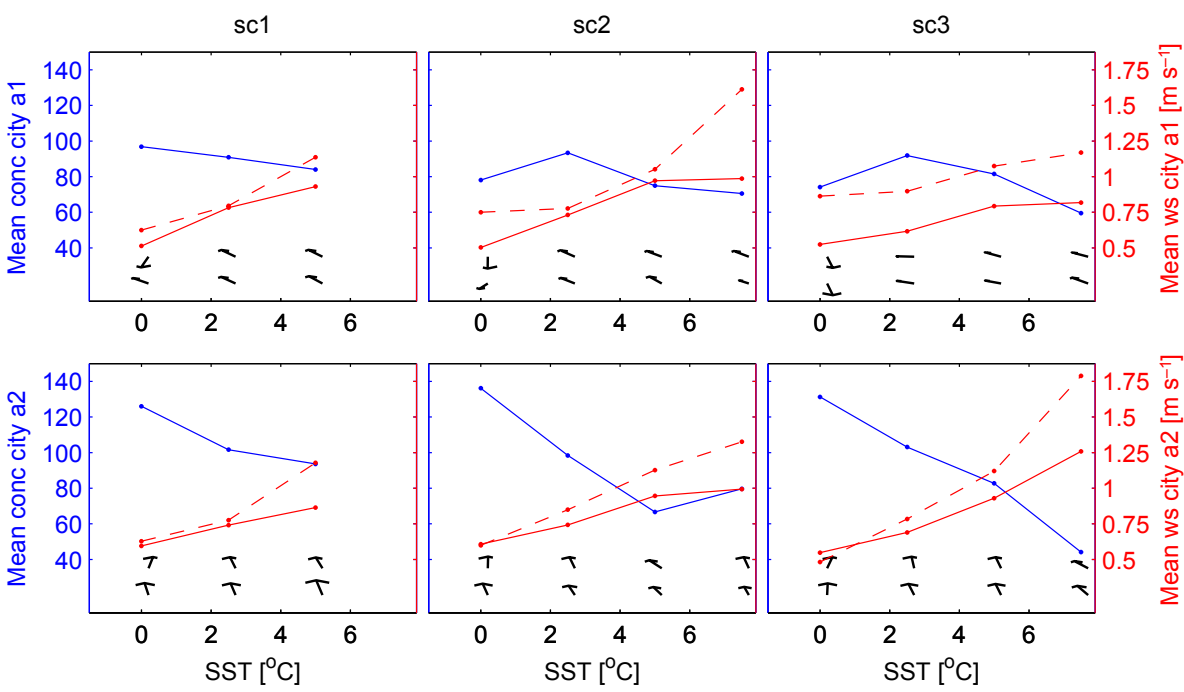

Figure 8. Mean passive tracer concentration (blue) and wind speed at $55 \mathrm{~m}$ (red, dashed) and $10 \mathrm{~m}$ above the surface (red, solid) for area 1 (a1) and 2 (a2), as indicated in Fig. 1 for the three wind-speed scenarios as indicated in Table 1. The wind vectors indicate the mean wind direction in the area at the $55 \mathrm{~m}$ height level (top panels) and $10 \mathrm{~m}$ above the ground (bottom panels). Vectors point into the direction of the flow. All data are averaged over the last four output steps of the $12 \mathrm{~h}$ simulations, corresponding to Fig. 7.

terior part of the valley. Furthermore, as the large water body in the middle of the valley is warmer than the surrounding land, it causes another centre of flow convergence similar to the fjord. It enhances an up-valley flow over area 1, while it weakens it for area 2. This effect is increasing with decreasing fjord surface temperature due to the changes in land surface temperature between the different model simulations. Especially for the cases with $0{ }^{\circ} \mathrm{C}$ fjord surface temperature, however, the convergence over the water body in the middle of the valley is most likely overestimated, since the brackish water lake usually cools off much faster than the fjord, resulting in a smaller temperature difference between the lakes and the surrounding land. A thin layer of ice, as it is typical on this water body, utterly reduces this effect.

The impact of the wind circulation on the dispersion of the passive tracer is two-fold. Locally, more stagnant conditions in area 1 lead to an increased accumulation of pollutants in this region. The concentration over area 2 is in general higher than over area 1, except for case 7. This part of the valley is more protected from the geostrophic winds than area 1. In addition, the wind direction plays a more important role for area 1. An up-valley flow automatically leads to a lower pollutant concentration there, since air from the fjord, with considerably lower tracer concentrations, will be transported inland.

\subsection{Analysis of single road contribution}

For many valleys the main pollutant emissions over land come from single transit roads. The same is the case for the $\mathrm{NO}_{2}$ emissions in the Bergen Valley. The main emission source for traffic-emitted pollutants is the transit road marked in Fig. 1. Emissions from a reduced area give insight into the efficiency of the horizontal dispersion for the most relevant areas that was obscured by the areal emissions assessed before. Therefore, we repeated cases 9 to 11 with tracer emissions only from this road. The wind fields, together with the passive tracer concentrations $2 \mathrm{~m}$ above the surface, are shown in Fig. 9. We chose to use sc 3 for the wind speeds in order to see the full range of conditions, from a down-valley flow to maximum stagnation.

The up-valley flow in case 13 transports the passive tracer away from the city centre. As the emissions from the street here are only scaling with the area covered by the street, ignoring traffic density and pattern for the emission factors, the large interchange road is causing the highest density of emissions. However, the high tracer concentrations are not transported to other places in the valley. They are rather caught by the convection from the lake in the middle of the valley, which also serves as an effective barrier for the tracer transport from this street. This is, to a lesser degree, also visible for the other two cases. Emissions from area 2 contribute less to the pollution directly north of the lake. This indicates that even relatively smaller interior water bodies could improve the urban ventilation through driving convective and localscale circulations.

For the other two cases, the mean down-valley flow transports the tracer along the valley axis. While for case 14 there is still an accumulation visible because of a relative stagnation, the down-valley flow is sufficiently strong and keeps the passive tracer concentrations at a low level over large parts of the city centre for case 15 . 


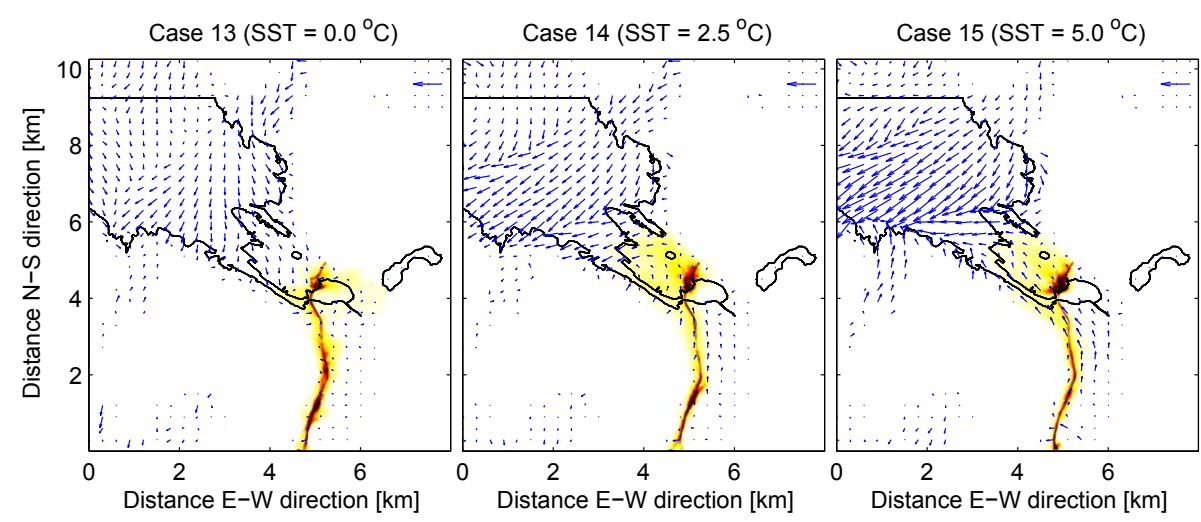

Figure 9. Same as Fig. 7 but for the cases with emissions only from the main street inside the Bergen Valley. The colour coding for the concentration is the same in all three panels, but different from Fig. 7. Shading is chosen to show the horizontal distribution of the pollutants and not the maximum values over the street.

\section{Summary and discussion}

In this study, we run a set of large-eddy simulations with PALM to evaluate the role of local circulations and their sensitivity to the interplay between external large-scale forcing and local forcing due to heterogeneities in the surface conditions. Specifically, we addressed the sea-land temperature difference, the large-scale wind speed and the imposed static stability of the lower atmosphere for typical conditions leading to high air pollution in Bergen, Norway.

Urban settlements in mountainous terrain at high latitudes are especially prone to adverse effects of temperature inversions on air quality. A lack of solar heating in winter and topographic constraints on the low-level atmospheric circulation can lead to an accumulation of air pollutants near the surface. At the same time, large sea-land surface temperature differences create local and meso-scale circulations in coastal cities, which can partially compensate or even overwhelm the low-level circulations forced by the large-scale atmospheric flow. Will the circulations due to the surface heterogeneity impact the urban ventilation and hence the air quality, and to what degree? The outcome depends not only on the case-specific geographical features of the terrain and the specific emissions in the city, but also on more universal physical mechanisms and scalings. Such dependencies have already been extensively studied for flat surfaces and more regular heterogeneities, e.g. those related to sea-ice fractures or leads in the Arctic Ocean (Esau, 2007) or to idealized surface plot patterns (van Heerwaarden et al., 2014). Published studies on urbanized mountain valleys often did not have sufficiently fine resolution to reproduce interactions between the flow above and the local flow features inside the valley. Moreover, they have not addressed these interactions in the stably stratified boundary layers, when air pollution may be particularly high.

The conducted joint analysis of the $\mathrm{NO}_{2}$ concentration and meteorological parameters for the Bergen Valley revealed an unexpected build-up of air pollution under synoptic situations with significant non-zero large-scale winds. There was a distinct maximum in the distribution of observed $\mathrm{NO}_{2}$ concentrations against the ERA-Interim surface wind speeds at around $3 \mathrm{~m} \mathrm{~s}^{-1}$. This behaviour is inconsistent with the usually assumed monotonic concentration-wind-speed dependencies and the faster depletion of valley cold air pools with increasing wind speeds (e.g. Zängl, 2003; Lareau and Horel, 2015). The behaviour of monotonically decreasing concentrations against wind speeds is, however, recovered for the actually measured surface winds. This indicates that some sufficiently strong local circulations emerge near the surface that are able to counteract the large-scale winds, but are not resolved in ERA-Interim. We therefore studied the physical mechanisms, dynamics, and sensitivities to the surface features for those circulations with a set of 16 PALM scenarios (Table 1) for the realistic terrain surrounding the city.

The simulations showed that, either the local circulation, forced by the large-scale flow, or the locally forced breeze circulation could dominate the dispersion of air pollution in the lower valley atmosphere. The maximum pollutant trapping under prevailing inversion conditions was dependent on the exact interplay of the three circulation features, i.e. large-scale flow, topographic steering, and breeze circulation. The simulations with the lowest fjord surface temperatures showed a mean up-valley flow dominated by the topographically steered recirculation of the large-scale flow. The pollution emitted from urban activities was represented by a passive tracer emitted from the land surface over the urban area. The up-valley winds therefore caused the advection of tracer-free air from over the fjord into the city centre. The simulations with the higher fjord surface temperatures showed a mean down-valley flow dominated by the breeze circulation. For the highest fjord surface temperatures this lead to an efficient depletion of the tracer emitted over the urban area. For the simulations with intermediate tempera- 
tures, however, both circulation features balanced each other, leading to local stagnation and an accumulation of the tracer.

Perhaps one of the most interesting implications of this study is the possibility to analyse pollution scenarios for a specific area induced by concrete emission sources. Such inverse diffusion problems are frequently solved through a Green function method for regular domains (Lin and Hildemann, 1996), but for irregular domains, the direct simulations remain more computationally efficient. The simulations demonstrated that the strongly localized concentrations are rather sensitive to small-scale convective sources such as interior lakes. These effectively work as barriers for the dispersion of pollutants near the ground. An approach to predicting local air quality without resolving such local features will not be able to simulate the pollutant dispersion pattern correctly.

Data availability. References for all data sets used in this publication are given in the text. All data sets are available on request from the stated sources. The ERA-Interim and topographic data sets have limitations for availability to the public due to restrictions on commercial use. Relevant contact persons are noted in the acknowledgements.

\section{The Supplement related to this article is available online at https://doi.org/10.5194/acp-17-7261-2017-supplement.}

Competing interests. The authors declare that they have no conflict of interest.

Acknowledgements. This study was funded by the GC Rieber foundation. We thank Bergen Municipality (Endre Leivestad) for provision of the topographic input data, the land-sea mask, and the position of roads in the Bergen Valley. We further thank the Norwegian Meteorological Institute and the Geophysical Institute at the University of Bergen (Anak Bhandari) for providing wind measurement data, the European Centre for Medium-Range Weather Forecasts for the ERA-Interim data, and the Norwegian Institute for Air Research (Rita Våler) for the air quality measurement data. Sigfried Raasch and Björn Maronga from the Institute of Meteorology and Climatology at the University of Hanover were helpful in adapting and applying the PALM code. CPU time was provided through the Norwegian Supercomputing Project (NOTUR II grant number nn2993k).

Edited by: V.-M. Kerminen

Reviewed by: two anonymous referees

\section{References}

Atlaskin, E. and Vihma, T.: Evaluation of NWP results for wintertime nocturnal boundary-layer temperatures over Europe and Finland, Q. J. Roy. Meteorol. Soc., 138, 1440-1451, https://doi.org/10.1002/qj.1885, 2012.

Baklanov, A., Hänninen, O., Slørdal, L. H., Kukkonen, J., Bjergene, N., Fay, B., Finardi, S., Hoe, S. C., Jantunen, M., Karppinen, A., Rasmussen, A., Skouloudis, A., Sokhi, R. S., Sørensen, J. H., and Ødegaard, V.: Integrated systems for forecasting urban meteorology, air pollution and population exposure, Atmos. Chem. Phys., 7, 855-874, https://doi.org/10.5194/acp-7-855-2007, 2007.

Baklanov, A. A., Grisogono, B., Bornstein, R., Mahrt, L., Zilitinkevich, S. S., Taylor, P., Larsen, S. E., Rotach, M. W., and Fernando, H. J. S.: The Nature, Theory, and Modeling of Atmospheric Planetary Boundary Layers, B. Am. Meteorol. Soc., 92, 123-128, https://doi.org/10.1175/2010BAMS2797.1, 2011.

Barlow, J. F.: Progress in observing and modelling the urban boundary layer, Urban Clim., 10, 216-240, https://doi.org/10.1016/j.uclim.2014.03.011, 2014.

Basu, S., Holtslag, A., Wiel, B., Moene, A., and Steeneveld, G.-J.: An inconvenient "truth" about using sensible heat flux as a surface boundary condition in models under stably stratified regimes, Acta Geophys., 56, 88-99, https://doi.org/10.2478/s11600-007-0038-y, 2008.

Beare, R. J., Macvean, M. K., Holtslag, A. A. M., Cuxart, J., Esau, I., Golaz, J.-C., Jimenez, M. A., Khairoutdinov, M., Kosovic, B., Lewellen, D., Lund, T. S., Lundquist, J. K., Mccabe, A., Moene, A. F., Noh, Y., Raasch, S., and Sullivan, P.: An Intercomparison of Large-Eddy Simulations of the Stable Boundary Layer, Bound.-Lay. Meteorol., 118, 247-272, https://doi.org/10.1007/s10546-004-2820-6, 2006.

Berge, E., Walker, S.-E., Sorteberg, A., Lenkopane, M., Eastwood, S., Jablonska, H. I., and Ødegaard Køltzow, M.: A Real-Time operational Forecast Model for Meteorology and Air Quality during Peak Air Pollution Episodes in Oslo, Norway, Water Air Soil Pollut. Focus, 2, 745-757, https://doi.org/10.1023/A:1021378005618, 2002.

Bergot, T., Escobar, J., and Masson, V.: Effect of small-scale surface heterogeneities and buildings on radiation fog: Large-eddy simulation study at Paris-Charles de Gaulle airport, Q. J. Roy. Meteorol. Soc., 141, 285-298, https://doi.org/10.1002/qj.2358, 2015.

Brümmer, B. and Schultze, M.: Analysis of a 7-year lowlevel temperature inversion data set measured at the $280 \mathrm{~m}$ high Hamburg weather mast, Meteorol. Z., 24, 481-494, https://doi.org/10.1127/metz/2015/0669, 2015.

Chen, F., Kusaka, H., Bornstein, R., Ching, J., Grimmond, C. S. B., Grossman-Clarke, S., Loridan, T., Manning, K. W., Martilli, A., Miao, S., Sailor, D., Salamanca, F. P., Taha, H., Tewari, M., Wang, X., Wyszogrodzki, A. A., and Zhang, C.: The integrated WRF/urban modelling system: Development, evaluation, and applications to urban environmental problems, Int. J. Climatol., 31, 273-288, https://doi.org/10.1002/joc.2158, 2011.

Cheng, W. C., Liu, C.-H., and Leung, D. Y. C.: Large-eddy simulation of turbulent transport in urban street canyons in different thermal stabilities, in: The Fifth International Symposium on Computational Wind Engineering (CWE2010), Chapel Hill, North Carolina, USA, available at: ftp://ftp.atdd.noaa.gov/pub/ cwe2010/Files/Papers/064_Liu.pdf (last access: 12 June 2017), 2010 . 
Crosman, E. T. and Horel, J. D.: Sea and Lake Breezes: A Review of Numerical Studies, Bound.-Lay. Meteorol., 137, 1-29, https://doi.org/10.1007/s10546-010-9517-9, 2010.

Crosman, E. T. and Horel, J. D.: Winter Lake Breezes near the Great Salt Lake, Bound.-Lay. Meteorol., 159, 439-464, https://doi.org/10.1007/s10546-015-0117-6, 2016.

Deardorff, J. W.: Stratocumulus-capped mixed layers derived from a three-dimensional model, Bound.-Lay. Meteorol., 18, 495-527, https://doi.org/10.1007/BF00119502, 1980.

Dee, D. P., Uppala, S. M., Simmons, A. J., Berrisford, P., Poli, P., Kobayashi, S., Andrae, U., Balmaseda, M. A., Balsamo, G., Bauer, P., Bechtold, P., Beljaars, A. C. M., van de Berg, L., Bidlot, J., Bormann, N., Delsol, C., Dragani, R., Fuentes, M., Geer, A. J., Haimberger, L., Healy, S. B., Hersbach, H., Hólm, E. V., Isaksen, L., Kållberg, P., Köhler, M., Matricardi, M., McNally, A. P., Monge-Sanz, B. M., Morcrette, J.-J., Park, B.-K., Peubey, C., de Rosnay, P., Tavolato, C., Thépaut, J.-N., and Vitart, F.: The ERA-Interim reanalysis: configuration and performance of the data assimilation system, Q. J. Roy. Meteorol. Soc., 137, 553597, https://doi.org/10.1002/qj.828, 2011.

ECMWF: MARS, the ECMWF archive, available at: https://software.ecmwf.int/wiki/display/UDOC/MARS+user+ documentation, last access: 30 September 2016.

Esau, I.: A Health Damage Pattern Due to Street-Level Pollution in the Central Paris Area Estimated With a Turbulence-Resolving Model, in: Sustainable Environmental Design in Architecture, vol. 56, edited by: Rassia, S. T. and Pardalos, P. M., Springer, New York, NY, 307-324, 2012.

Esau, I. N.: Amplification of turbulent exchange over wide Arctic leads: Large-eddy simulation study, J. Geophys. Res., 112, D08109, https://doi.org/10.1029/2006JD007225, 2007.

Fay, B. and Neunhäuserer, L.: Evaluation of high-resolution forecasts with the non-hydrostaticnumerical weather prediction model Lokalmodell for urban air pollutionepisodes in Helsinki, Oslo and Valencia, Atmos. Chem. Phys., 6, 2107-2128, https://doi.org/10.5194/acp-6-2107-2006, 2006.

Fernando, H. J. S.: Fluid Dynamics of Urban Atmospheres in Complex Terrain, Annu. Rev. Fluid Mech., 42, 365-389, https://doi.org/10.1146/annurev-fluid-121108-145459, 2010.

Fernando, H. J. S. and Weil, J. C.: Whither the stable boundary layer?, B. Am. Meteorol. Soc., 91, 1475-1484, https://doi.org/10.1175/2010BAMS2770.1, 2010.

Gariazzo, C., Papaleo, V., Pelliccioni, A., Calori, G., Radice, P., and Tinarelli, G.: Application of a Lagrangian particle model to assess the impact of harbour, industrial and urban activities on air quality in the Taranto area, Italy, Atmos. Environ., 41, 64326444, https://doi.org/10.1016/j.atmosenv.2007.06.005, 2007.

Glazunov, A., Rannik, Ü., Stepanenko, V., Lykosov, V., Auvinen, M., Vesala, T., and Mammarella, I.: Large-eddy simulation and stochastic modeling of Lagrangian particles for footprint determination in the stable boundary layer, Geosci. Model Dev., 9, 2925-2949, https://doi.org/10.5194/gmd-9-2925-2016, 2016.

Grange, S. K., Salmond, J. A., Trompetter, W. J., Davy, P. K., and Ancelet, T.: Effect of atmospheric stability on the impact of domestic wood combustion to air quality of a small urban township in winter, Atmos. Environ., 70, 28-38, https://doi.org/10.1016/j.atmosenv.2012.12.047, 2013.

Hoch, S. W., Whiteman, C. D., and Mayer, B.: A Systematic Study of Longwave Radiative Heating and Cooling within
Valleys and Basins Using a Three-Dimensional Radiative Transfer Model, J. Appl. Meteorol. Clim., 50, 2473-2489, https://doi.org/10.1175/JAMC-D-11-083.1, 2011.

Holmer, B., Haeger-eugensson, M., Holmer, B., and Haegereugensson, M.: Winter land breeze in a high latitude complex coastal area, Phys. Geogr., 20, 152-172, https://doi.org/10.1080/02723646.1999.10642674, 1999.

Hughes, J. K., Ross, A. N., Vosper, S. B., Lock, A. P., and JemmettSmith, B. C.: Assessment of valley cold pools and clouds in a very high-resolution numerical weather prediction model, Geosci. Model Dev., 8, 3105-3117, https://doi.org/10.5194/gmd8-3105-2015, 2015.

Junk, J., Helbig, A., and Lüers, J.: Urban climate and air quality in Trier Germany, Int. J. Biometeorol., 47, 230-238, https://doi.org/10.1007/s00484-003-0162-6, 2003.

Keck, M., Raasch, S., Letzel, M. O., and Ng, E.: First Results of High Resolution Large-Eddy Simulations of the Atmospheric Boundary Layer, J. Heat Isl. Inst. Int., 9, 39-43, 2014.

Lappalainen, H. K., Kerminen, V.-M., Petäjä, T., Kurten, T., Baklanov, A., Shvidenko, A., Bäck, J., Vihma, T., Alekseychik, P., Andreae, M. O., Arnold, S. R., Arshinov, M., Asmi, E., Belan, B., Bobylev, L., Chalov, S., Cheng, Y., Chubarova, N., de Leeuw, G., Ding, A., Dobrolyubov, S., Dubtsov, S., Dyukarev, E., Elansky, N., Eleftheriadis, K., Esau, I., Filatov, N., Flint, M., Fu, C., Glezer, O., Gliko, A., Heimann, M., Holtslag, A. A. M., Hõrrak, U., Janhunen, J., Juhola, S., Järvi, L., Järvinen, H., Kanukhina, A., Konstantinov, P., Kotlyakov, V., Kieloaho, A.-J., Komarov, A. S., Kujansuu, J., Kukkonen, I., Duplissy, E.-M., Laaksonen, A., Laurila, T., Lihavainen, H., Lisitzin, A., Mahura, A., Makshtas, A., Mareev, E., Mazon, S., Matishov, D., Melnikov, V., Mikhailov, E., Moisseev, D., Nigmatulin, R., Noe, S. M., Ojala, A., Pihlatie, M., Popovicheva, O., Pumpanen, J., Regerand, T., Repina, I., Shcherbinin, A., Shevchenko, V., Sipilä, M., Skorokhod, A., Spracklen, D. V., Su, H., Subetto, D. A., Sun, J., Terzhevik, A. Y., Timofeyev, Y., Troitskaya, Y., Tynkkynen, V.P., Kharuk, V. I., Zaytseva, N., Zhang, J., Viisanen, Y., Vesala, T., Hari, P., Hansson, H. C., Matvienko, G. G., Kasimov, N. S., Guo, H., Bondur, V., Zilitinkevich, S., and Kulmala, M.: PanEurasian Experiment (PEEX): towards a holistic understanding of the feedbacks and interactions in the land-atmosphere-oceansociety continuum in the northern Eurasian region, Atmos. Chem. Phys., 16, 14421-14461, https://doi.org/10.5194/acp-1614421-2016, 2016.

Lareau, N. P. and Horel, J. D.: Dynamically Induced Displacements of a Persistent Cold-Air Pool, Bound.-Lay. Meteorol., 154, 291316, https://doi.org/10.1007/s10546-014-9968-5, 2015.

Lareau, N. P., Crosman, E., Whiteman, C. D., Horel, J. D., Hoch, S. W., Brown, W. O. J., and Horst, T. W.: The Persistent Cold-Air Pool Study, B. Am. Meteorol. Soc., 94, 51-63, https://doi.org/10.1175/BAMS-D-11-00255.1, 2013.

Letzel, M. O., Krane, M., and Raasch, S.: High resolution urban large-eddy simulation studies from street canyon to neighbourhood scale, Atmos. Environ., 42, 8770-8784, https://doi.org/10.1016/j.atmosenv.2008.08.001, 2008.

Letzel, M. O., Helmke, C., Ng, E., An, X., Lai, A., and Raasch, S.: LES case study on pedestrian level ventilation in two neighbourhoods in Hong Kong, Meteorol. Z., 21, 575-589, https://doi.org/10.1127/0941-2948/2012/0356, 2012. 
Lin, J.-S. and Hildemann, L. M.: Analytical solutions of the atmospheric diffusion equation with multiple sources and heightdependent wind speed and eddy diffusivities, Atmos. Environ., 30, 239-254, https://doi.org/10.1016/1352-2310(95)002879, 1996.

Lo, J. C. F., Lau, A. K. H., Fung, J. C. H., and Chen, F.: Investigation of enhanced cross-city transport and trapping of air pollutants by coastal and urban land-sea breeze circulations, J. Geophys. Res., 111, D14104, https://doi.org/10.1029/2005JD006837, 2006.

Lüpkes, C., Gryanik, V. M., Witha, B., Gryschka, M., Raasch, S., and Gollnik, T.: Modeling convection over arctic leads with LES and a non-eddy-resolving microscale model, J. Geophys. Res., 113, C09028, https://doi.org/10.1029/2007JC004099, 2008.

Mahrt, L.: Stably Stratified Atmospheric Boundary Layers, Annu. Rev. Fluid Mech., 46, 23-45, https://doi.org/10.1146/annurevfluid-010313-141354, 2014.

Maronga, B., Gryschka, M., Heinze, R., Hoffmann, F., KananiSühring, F., Keck, M., Ketelsen, K., Letzel, M. O., Sühring, M., and Raasch, S.: The Parallelized Large-Eddy Simulation Model (PALM) version 4.0 for atmospheric and oceanic flows: model formulation, recent developments, and future perspectives, Geosci. Model Dev., 8, 2515-2551, https://doi.org/10.5194/gmd-8-2515-2015, 2015.

Mason, P. J. and Derbyshire, S. H.: Large-Eddy Simulation of the stably-stratified atmospheric boundary layer, Bound.-Lay. Meteorol., 53, 117-162, https://doi.org/10.1007/BF00122467, 1990.

Moeng, C.-H. and Wyngaard, J. C.: Spectral analysis of large-eddy simulations of the convective boundary layer, J. Atmos. Sci., 45, 3573-3587, https://doi.org/10.1175/15200469(1988)045<3573:SAOLES>2.0.CO;2, 1988.

Mohamad, A. A. and Viskanta, R.: Flow and heat transfer in a lid-driven cavity filled with a stably stratified fluid, Appl. Math. Model., 19, 465-472, https://doi.org/10.1016/0307904X(95)00030-N, 1995.

Nakayama, H., Takemi, T., and Nagai, H.: Large-eddy simulation of urban boundary-layer flows by generating turbulent inflows from mesoscale meteorological simulations, Atmos. Sci. Lett., 13, 180-186, https://doi.org/10.1002/asl.377, 2012.

Nordbo, A., Järvi, L., and Vesala, T.: Revised eddy covariance flux calculation methodologies - effect on urban energy balance, Tellus B, 64, 1-20, https://doi.org/10.3402/tellusb.v64i0.18184, 2012.

Norwegian Institute for Air Research: Luftkvaliteten i Norge, available at: http://admin.luftkvalitet.info, last access: 30 September 2016.

Norwegian Meteorological Institute: eKlima, the climate database of the Norwegian Meteorological Institute, available at: http://sharki.oslo.dnmi.no/portal/page?_pageid=73,39035,

73_39101\&_dad=portal\&_schema=PORTAL, last access: 30 September 2016.

Park, S.-B., Baik, J.-J., and Lee, S.-H.: Impacts of Mesoscale Wind on Turbulent Flow and Ventilation in a Densely Builtup Urban Area, J. Appl. Meteorol. Clim., 54, 811-824, https://doi.org/10.1175/JAMC-D-14-0044.1, 2015a.

Park, S.-B., Baik, J.-J., and Han, B.-S.: Large-eddy simulation of turbulent flow in a densely built-up urban area, Environ. Fluid Mech., 15, 235-250, https://doi.org/10.1007/s10652-013-9306$3,2015 b$.
Patnaik, G. and Boris, J.: FAST3D-CT: an LES model for urban aerodynamics, in: The Fifth International Symposium on Computational Wind Engineering (CWE2010), Chapel Hill, North Carolina, USA, available at: ftp: //ftp.atdd.noaa.gov/pub/cwe2010/Files/Papers/394_Patnaik.pdf (last access: 12 June 2017), 2010.

Raasch, S. and Schröter, M.: PALM - A large-eddy simulation model performing on massively parallel computers, Meteorol. Z., 10, 363-372, https://doi.org/10.1127/09412948/2001/0010-0363, 2001.

Reeves, H. D. and Stensrud, D. J.: Synoptic-Scale Flow and Valley Cold Pool Evolution in the Western United States, Weather Forecast., 24, 1625-1643, https://doi.org/10.1175/2009WAF2222234.1, 2009.

Rimetz-Planchon, J., Perdrix, E., Sobanska, S., and Brémard, C.: $\mathrm{PM}_{10}$ air quality variations in an urbanized and industrialized harbor, Atmos. Environ., 42, 7274-7283, https://doi.org/10.1016/j.atmosenv.2008.07.005, 2008.

Rotach, M. W., Calanca, P., Graziani, G., Gurtz, J., Steyn, D. G., Vogt, R., Andretta, M., Christen, A., Cieslik, S., Connolly, R., De Wekker, S. F. J., Galmarini, S., Kadygrov, E. N., Kadygrov, V., Miller, E., Neininger, B., Rucker, M., Van Gorsel, E., Weber, H., Weiss, A., and Zappa, M.: Turbulence Structure and Exchange Processes in an Alpine Valley: The Riviera Project, B. Am. Meteorol. Soc., 85, 1367-1385, https://doi.org/10.1175/BAMS-85-9-1367, 2004.

Saiki, E. M., Moeng, C., and Sullivan, P. P.: Large Eddy Simulation of the stably stratified planetary boundary layer, Bound.-Lay. Meteorol., 95, 1-30, https://doi.org/10.1023/A:1002428223156, 2000.

Schalkwijk, J., Jonker, H. J. J., Siebesma, A. P., and Van Meijgaard, E.: Weather Forecasting Using GPU-Based LargeEddy Simulations, B. Am. Meteorol. Soc., 96, 715-723, https://doi.org/10.1175/BAMS-D-14-00114.1, 2015.

Schicker, I. and Seibert, P.: Simulation of the meteorological conditions during a winter smog episode in the Inn Valley, Meteorol. Atmos. Phys., 103, 211-222, https://doi.org/10.1007/s00703008-0346-z, 2009.

Sheridan, P. F., Vosper, S. B., and Brown, A. R.: Characteristics of cold pools observed in narrow valleys and dependence on external conditions, Q. J. Roy. Meteorol. Soc., 140, 715-728, https://doi.org/10.1002/qj.2159, 2014.

Steyn, D. G., DeWekker, S. F. J., Kossmann, M., and Martilli, A.: Boundary Layers and Air Quality in Mountainous Terrain, in: Mountain Weather Research and Forecasting, edited by: Chow, F. K., De Wekker, S. F. J., and Snyder, B. J., Springer Netherlands, Dordrecht, 261-289, 2013.

Tomas, J. M., Pourquie, M. J. B. M., and Jonker, H. J. J.: Stable Stratification Effects on Flow and Pollutant Dispersion in Boundary Layers Entering a Generic Urban Environment, Bound.Lay. Meteorol., 159, 221-239, https://doi.org/10.1007/s10546015-0124-7, 2016.

van Heerwaarden, C. C., Mellado, J. P., and de Lozar, A.: Scaling Laws for the Heterogeneously Heated Free Convective Boundary Layer, J. Atmos. Sci., 71, 3975-4000, https://doi.org/10.1175/JAS-D-13-0383.1, 2014.

Whiteman, C. D. and Doran, J. C.: The Relationship between Overlying Synoptic-Scale Flows and Winds within a Valley, J. 
Appl. Meteorol., 32, 1669-1682, https://doi.org/10.1175/15200450(1993)032<1669:TRBOSS>2.0.CO;2, 1993.

Wicker, L. J. and Skamarock, W. C.: Time-Splitting Methods for Elastic Models Using Forward Time Schemes, Mon. Weather Rev., 130, 2088-2097, https://doi.org/10.1175/15200493(2002)130<2088:TSMFEM>2.0.CO;2, 2002.

Wolf, T. and Esau, I.: A proxy for air quality hazards under present and future climate conditions in Bergen, Norway, Urban Clim., 10, 801-814, https://doi.org/10.1016/j.uclim.2014.10.006, 2014.

Wolf, T., Esau, I., and Reuder, J.: Analysis of the vertical temperature structure in the Bergen valley, Norway, and its connection to pollution episodes, J. Geophys. Res.-Atmos., 119, 10645-10662, https://doi.org/10.1002/2014JD022085, 2014.

Wyszogrodzki, A. A., Miao, S., and Chen, F.: Evaluation of the coupling between mesoscale-WRF and LES-EULAG models for simulating fine-scale urban dispersion, Atmos. Res., 118, 324345, https://doi.org/10.1016/j.atmosres.2012.07.023, 2012.

Xie, Z. T., Hayden, P., and Wood, C. R.: Large-eddy simulation of approaching-flow stratification on dispersion over arrays of buildings, Atmos. Environ., 71, 64-74, https://doi.org/10.1016/j.atmosenv.2013.01.054, 2013.
Zängl, G.: The impact of upstream blocking, drainage flow and the geotrophic pressure gradient on the persistence of cold-air pools, Q. J. Roy. Meteorol. Soc., 129, 117-137, https://doi.org/10.1256/qj.02.99, 2003.

Zhang, J. P., Zhu, T., Zhang, Q. H., Li, C. C., Shu, H. L., Ying, Y., Dai, Z. P., Wang, X., Liu, X. Y., Liang, A. M., Shen, H. X., and Yi, B. Q.: The impact of circulation patterns on regional transport pathways and air quality over Beijing and its surroundings, Atmos. Chem. Phys., 12, 5031-5053, https://doi.org/10.5194/acp12-5031-2012, 2012.

Zhong, S., Whiteman, C. D., Bian, X., Shaw, W. J., and Hubbe, J. M.: Meteorological Processes Affecting the Evolution of a Wintertime Cold Air Pool in the Columbia Basin, Mon. Weather Rev., 129, 2600-2613, https://doi.org/10.1175/15200493(2001)129<2600:MPATEO>2.0.CO;2, 2001.

Zilitinkevich, B. S., Kulmala, M., and Esau, I.: Megacities - Refining Models to Client Environment, WMO Bull., 64, 20-22, 2015. 